\title{
PERANAN PANGLIMA LAOT LHOK DALAM PENGELOLAAN SUMBERDAYA LAUT BERBASIS ADAT DI KECAMATAN MESJID RAYA KABUPATEN ACEH BESAR
}

\author{
(The Role Of Panglima Laot Lhok In The Management Marine Resources Based On \\ Custom In Kecamatan Mesjid Raya Kabupaten Aceh Besar )
}

\author{
Zaitun Munar, Agussabti ${ }^{1}$, Irwan A. Kadir ${ }^{*}$ \\ ${ }^{1}$ Program Studi Agribisnis, Fakultas Pertanian, Universitas Syiah Kuala
}

\begin{abstract}
Abstrak. Panglima Laot lhok adalah pemimpin nelayan yang secara hukum adat laut (hukum adat laot) bertugas mengkoordinasikan satu atau lebih wilayah operasional nelayan, dan minimal satu pemukiman nelayan. Panglima Laot lhok mempunyai fungsi untuk mengatur pengaturan penangkapan ikan dan mempunyai kewenangan untuk menyelesaikan sengketa, perselisihan dan pelanggaran yang terjadi diantara nelayan dan memberikan sanksi kepada si pelanggar sesuai dengan ketentuan hukum adat laut. Penelitian ini bertujuan untuk mengetahui kondisi eksisting panglima laot lhok, untuk mengetahui peranan panglima laot lhok dalam pengelolaan sumberdaya laut berbasis adat dan mengidentifikasi faktor -faktor yang mempengaruhi persepsi nelayan terhadap peran panglima laot lhok. Lokasi penelitian yaitu di Kecamatan Masjid raya Kabupaten Aceh Besar. Jumlah sample ditentukan secara purposive sampling yaitu 40 sampel. Penelitian ini menggunakan metode Skala Likert, deskriptif dan analisis regresi linier berganda. Hasil penelitian didapat bahwa keradaan Panglima Laot Di Kecamatan Masjid Raya masih aktif, dapat kita lihat hukum adat masih dijalani oleh para nelayan. Peranan panglima laot lhok di kecamatan masjid raya berada pada kategori berperan . Faktor yang mempengaruhi persepsi nelayan terhadap peran Panglima Laot Lhok yaitu variabel Kapasitas panglima laot lhok (X1), kepribadian (X2), hubungan sosial (X4) dan lingkungan (X5), secara simultan semua faktor-faktor tersebut mempengaruhi peran panglima laot lhok.
\end{abstract}

Kata kunci : Peranan, Panglima Laot Lhok, Pengelolaan Sumberdaya Laut

Abstract. Panglima Laot lhok is a fisherman leader who is legally marine (laot customary law) in charge of coordinating one or more fishermen's operational areas, and at least one fisherman's settlement. Panglima Laot lhok has a function to regulate fishing arrangements and has the authority to resolve disputes, disputes and violations that occur between fishermen and sanction the offenders in accordance with the provisions of customary law of the sea. This study aims to determine the existing condition of commander laot lhok, to know the role of commander laot lhok in the management of marine resources based on adat and identify factors influencing perception of fisherman to role of commander of laot lhok. The research location is in kecamatan Masjid raya kabupaten Aceh Besar. The number of samples is determined by purposive sampling that is 40 samples. This research uses Likert Scale method, descriptive and multiple linear regression analysis. The results obtained that the presence of Panglima Laot In kecamatan Masjid Raya is still active, we can see the customary law is still undertaken by the fishermen. The role of commander of laot lhok in sub-district of mosque is in the role category. Factors influencing the perception of fishermen on the role Panglima Laot Lhok are the variables Capacity panglima laot lhok $(X 1)$, personality (X2), social relations (X4) and environment (X5), simultaneously all these factors affect the role of panglima laot lhok.

Key Words : Role, Panglima Laot Lhok, Marine Resource Management

\section{PENDAHULUAN}

Aceh memiliki pola kelembagaan yang menempatkan panglima laot sebagai industri dalam ketentuan/aturan yang lebih luas. Panglima laot menetapkan batas-batas ketentuan adat mengenai sistem pengelolaan sumber daya laut dan masalah-masalah pelaksanaan sosial dalam suatu ketetapan adat. Panglima laot memimpin kawasankawasan yang disebut dengan lhok. Lhok merupakan satuan lokasi tempat nelayan melabuhkan perahunya, menjual ikan atau berdomosili. Lhok biasanya berupa pantai atau

*corresponding author :Irwanakadir@unsyiah.ac.id 
teluk, bisa mencakup wilayah seluas sebuah desa/ gampong, kecamatan/ mukim, bahkan satu gugus kepuluan.dengan menentukan tata batas dan tata kelola konservasi yang dari sana diterapkan hukum.

Pada dasarnya, penggolongan sosial dalam masyarakat nelayan dapat ditinjau dari sudut pandang. Pertama, dari segi penguasaan alat-alat produksi atau peralatan tangkap (perahu, jaring dan perlengkapan yang lain), struktur masyarakat nelayan terbagi ke dalam kategori nelayan pemilik (alat-alat produksi) dan nelayan buruh. Kedua, ditinjau dari tingkat skala investasi modal usahanya, struktur masyarakat nelayan terbagi ke dalam kategori nelayan besar dan nelayan kecil. Ketiga, ditinjau dari tingkat teknologi peralatan tangkap yang digunakan, masyarakat nelayan terbagi ke dalam kategori nelayan modern dan nelayan tradisional (Kusnadi, 2002).

Sumberdaya perikanan di Aceh juga termasuk sebagai bagian dari kondisi perikanan kritis Indonesia, akibat produksi perikanan yang meningkat tajam dalam 50 tahun terakhir, yakni 19,3 juta ton pada tahun 1950 menjadi 134 juta ton pada tahun 2002. Produksi perikanan berdasarkan peningkatan penangkapan ikan dari 16,7 juta ton pada tahun 1950 menjadi 81,5 juta ton pada 2003. Jumlah 16,7 juta ton pada tahun 1950 sebanding dengan $86 \%$ dari total produksi perikanan dunia. Sedangkan sekarang produksi perikanan indonesia tidak sampai $20 \%$ dari perikanan dunia. Pada masa sekarang potensi lestari perikanan di indonesia sebesar 79,37\%. Sementara itu pemanfaatan perikanan di perairan selat malaka mencapai $176,3 \%$ dari potensi lestari (Gopakumar, 2002).

Pengelolaan sumberdaya pesisir pada dasarnya memiliki tujuan untuk meningkatkan kesejahteraan seluruh masyarakat secara berkelanjutan, terutama komunitas masyarakat lokal yang bermukim di wilayah pesisir (coastal zone). Oleh karena itu, dalam pemanfaatan sumberdaya pesisir, aspek ekologi dalam hal kelestarian sumberdaya dan fungsi-fungsi ekosistem harus dipertahankan sebagai landasan utama untuk mencapai kesejahteraan tersebut. Pemanfaatan sumberdaya pesisir diharapkan tidak menyebabkan rusaknya fishing ground, spawning ground, maupun nursery ground ikan; selain itu juga tidak merusak fungsi ekosistem hutan bakau (mangrove), terumbu karang (coral reefs), dan padang lamun (sea grass) yang memiliki keterkaitan ekologis dengan keberlanjutan sumberdaya di wilayah pesisir..

Hukum adat laot adalah hukum adat yang sudah sejak lama dipergunakan dalam keseharian masyarakat Aceh, sebenarnya hukum adat laot bukan menjadi hal yang baru lagi, semenjak masa kerajaan Sultan Iskandar Muda, hukum adat yang mengatur tentang tata cara pengelolaan kelautan sudah digunakan. Sejalan dengan adanya hukum adat laot, pelaksanaan hukum adat diterapkan melalui perantara lembaga Panglima adat laot, gelar Panglima Laot untuk pemimpin sebuah lembaga adat laot merupakan sebuah gelar yang unik, sebuah keistimewaan tersendiri bagi siapa yang menjabatnya. Dari namanya, gelar panglima laot sarat dengan kekuasaan dan jabatan. Pada zaman Sultan Iskandar Muda (1607-1636) panglima laot diangkat resmi oleh sultan. Tugasnya selain memberdayakan ekonomi kawasan juga menjadi alat pertahanan dan keamanan di laut.Untuk mengembangkan tugas tersebut, panglima laot diberi kekuasaan menyelenggarakan peradilan dan melaksanakan setiap putusan yang dibuatnya (T. Djuned, 2001).

Dalam pola kemasyarakatan, dalam konteks hukum adat laut, kepentingan umum saling dihormati dan diakui yang pola pelaksanaannya berawal dari apa yang berlangsung lambat laun disepakati sebagai sebuah pola kehidupan bersama dalam mengelola sumberdaya dalam kehidupan masyarakat. Pola kehidupan dalam mengelola sumberdaya 
secara berkelanjutan, sebenarnya sudah merupakan pola pengendalian yang berbasis masyarakat. Pola ini akan berjalan efektif karena dalam pelaksanaan pengawasan terhadap perilaku yang tidak sesuai, tidak memerlukan biaya dan tenaga khusus, melainkan oleh mereka sendiri ( Sulaiman, 2012).

Kabupaten Aceh Besar, Alokasi Dana Desa (ADD) yang diterimana yaitu sebesar Rp350.971.062.000 untuk dibagikan kepada 604 Desa, termasuk Desa Neuheun dan Desa Baro Kecamatan Masjid Raya, Desa Lamlueng dan Desa Reukih Keupula kecamatan Indrapuri, serta Desa Jantho Makmur dan Desa Suka Tani Kecamatan Jantho. Alokasi Dana Desa ini diprioritaskan untuk membiayai pembangunan dan pemberdayaan masyarakat yang meliputi Pemenuhan Kebutuhan Dasar, Pembangunan Sarana dan Prasarana gampong, Pengembangan Potensi Ekonomi Lokal, dan Pemanfaatan sumber daya alam dan lingkungan secara berkelanjutan (Peraturan Bupati Aceh Besar No. 1, 2016).

Berbagai kendala dalam masyarakat nelayan di Kecamatan masjid raya masih ditemukan seperti kurangnya tersedia sarana dan prasarana pendukung kegiatan perikanan yang menyebabkan produktivitas rendah, pelaksanaan kegiatan perikanan yang masih tradisional dikarenakan alat tangkap yang digunakan masih berteknologi rendah dan tingkat pengetahuan dari masyarakat nelayan sendiri masih tergolong rendah. Oleh karena itu peran panglima laot yang sangat dibutuhkan disini untuk membina dan mengembangkan masyarakat nelayan sehingga diharapkan dapat meningkatkan kesejahteraan masyarakat itu sendiri .Tujuan dari penelitian ini yaitu untuk mengetahui Kondisi Eksisting Panglima Laot Lhok, untuk mengetahui peranan panglima laot lhok dan mengidentifikasi faktor-faktor yang mempengaruhi persepsi nelayan terhadap peran panglima laot lhok.

\section{METODE PENELITIAN}

Penelitian dilakukan di Kecamatan Masjid Raya Kabupaten Aceh Besar. Lokasi yaitu mukim lamnga dan mukim krueng raya,. Objek penelitian ini adalah pemuka hukum adat laot (panglima laot lhok) serta nelayan yang akan melaksanakan hukum dan adat laot. Ruang lingkup penelitian ini terbatas pada Peranan Panglima Laot Dalam Pengelolaan Sumberdaya Laut Berbasis Adat Di Kecamatan Masjid Raya Kabupaten Aceh Besar, pada peranan panglima laot lhok dan faktor-faktor yang mempengaruhi persepsi nelayan terhadap peran panglima laot digunakan untuk meningkatkan peranan panglima laot lhok dalam pengelolaan sumberdaya laut berbasis adat.

Metode yang digunakan dalam penelitian ini adalah metode Survey. Pengambilan jumlah sampel dalam penelitian ini dilakukan dengan menggunakan purposive Sampling. sampel yang ditetapkan yaitu berjumlah 40 sampel. Metode analisis yang digunakan dalam penelitian ini yaitu Skala Likert, deskriptif, dan analisis regresi linier berganda dengan bantuan software SPSS (Statistical Package for Social Sciences).

\section{Kondisi Eksisting (Keberadaan) Panglima Laot Lhok}

Untuk mengetahui kondisi eksisting ( keberadaan ) panglima laot lhok di daerah penelitian yaitu menggunakan metode deskriptif dengan pendekatan kualitatif. Penjelasan yang akan dianalisis yaitu keberadaan panglima laot di lokasi penelitian secara fisik serta tingkat kedinamisan / keaktifan panglima laot lhok di lokasi penelitian.

\section{Peranan panglima laot lhok}

Pengukuran indikator untuk mengetahui peran panglima laot lhok dilakukan dengan Skala Likert. Kriteria peran panglima laot lhok berkisar antara 24 sampai 72. 
Penentuan rentang skala untuk kriteria penafsiran nilai dan kategori menggunakan rumus sebagai berikut : (Putra, 2014)

Keterangan :

$$
\mathrm{RS}=\frac{(\mathrm{m}-\mathrm{n})}{\mathrm{b}}
$$

$$
\begin{array}{ll}
\mathrm{RS} & =\text { Rentang Skala } \\
\mathrm{m} & =\text { Skor tertinggi dalam pengukuran } \\
\mathrm{n} & =\text { Skor terendah dalam pengukuran } \\
\mathrm{b} & =\text { Kategori yang dibentuk }
\end{array}
$$

Sehimgga kriteria penafsiran nilai dan kategori untuk penilaian kinerja aparatur desa dalam implementasi Alokasi Dana Desa (ADD) sebagai berikut :

Tabel 1. Nilai dan kategori hasil evaluasi penilaian peran panglima laot lhok

\begin{tabular}{ccc}
\hline No. & Nilai & Kategori \\
\hline 1. & $24-39$ & Kurang Berperan \\
2. & $40-55$ & Cukup Berperan \\
3. & $56-72$ & Berperan \\
\hline
\end{tabular}

Sumber : Data primer (diolah) 2018

3. Faktor-Faktor yang mempengaruhi persepsi nelayan terhadap peran panglima laot lhok

Pada tujuan yang membahas tentang pengaruh antara variabel bebas dan variabel terikat digunakan metode regresi. Analisis regresi linier berganda bermaksud meramalkan bagaimana keadaan (naik turunnya) variabel dependen (kriterium), bila dua atau lebih variabel independen sebagai faktor prediator dimanipulasi (dinaik turunkan nilainya). Jadi analisis regresi berganda akan dilakukan bila jumlah variabel independennya minimal 2 (Sugiyono 2009). Jadi untuk melihat pengaruh antara variabel Independent (variabel bebas) yaitu kapasitas panglima laot lhok (X1), kepribadian (X2), hubungan sosial (X3) dan lingkungan (X4) dengan variabel Dependent (variebel terikat) yaitu peran panglima laot lhok (Y) digunakan uji statistik Rank Spearman dengan rumus :

$$
\mathrm{Y}=\mathrm{a}+\mathrm{b}_{1} \mathrm{X}_{1}+\mathrm{b}_{2} \mathrm{X}_{2}+\mathrm{b}_{3} \mathrm{X}_{3}+\mathrm{b}_{4} \mathrm{X}_{4}+\mathrm{e}
$$

Keterangan :

$$
\begin{array}{ll}
\mathrm{Y} & =\text { Peran panglima laot lhok } \\
\mathrm{a} & =\text { konstanta } \\
\mathrm{b}_{1}-\mathrm{b}_{4} & =\text { Koefisien Variabel } \\
\mathrm{X}_{1} & =\text { Kapasitas Panglima Laot Lhok } \\
\mathrm{X}_{2} & =\text { Kepribadian } \\
\mathrm{X}_{3} & =\text { Hubungan Sosial } \\
\mathrm{X}_{4} & =\text { Lingkungan } \\
\mathrm{e} & =\text { faktor-faktor yang tidak terobservasi (error) }
\end{array}
$$

Kriteria Keputusan :

$\mathrm{Ha} \quad$ : kapasitas panglima laot lhok, kepribadian, hubungan sosial dan lingkungan berpengaruh terhadap peran panglima laot lhok.

Ho : kapasitas panglima laot lhok, kepribadian, hubungan sosial dan lingkungan tidak berpengaruh terhadap peran panglima laot lhok. 
Dimana :

Fhitung $>$ Ftabel, pada taraf nyata 0,05 maka terima $\mathrm{Ha}_{\text {dan }}$ tolak $\mathrm{H}_{0}$

Fhitung $<\mathrm{F}$ tabel, pada taraf nyata 0,05 maka terima $\mathrm{H} 0$ dan tolak $\mathrm{Ha}$

Uji $t$ bertujuan untuk mengetahui besarnya pengaruh masing-masing variabel independent secara individual (parsial) terhadap variabel dependent. Pada regresi berganda, mungkin variabel X1, X2, X3,.., Xn secara bersama-sama berpengaruh nyata. Namun demikian, belum tentu secara individual atau parsial seluruh variabel tersebut berpengaruh nyata terhadap variabel dependentnya (Y).

Dengan ketentuan :

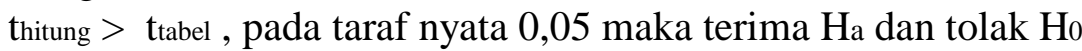

thitung $<$ tabel, pada taraf nyata 0,05 maka terima $\mathrm{H} 0$ dan tolak $\mathrm{Ha}$

Model regresi linear berganda disebut sebagai model yang baik apabila model tersebut memenuhi asumsi normalitas data dan terbebas dari asumsi klasik statistik yang meliputi multikolineritas, autokorelasi dan heteroskesdastisitas. Proses uji asumsi klasik dilakukan secara bersamaan dengan proses uji regresi. Pada penelitian ini dilakukan tiga uji asumsi, yaitu normalitas, multikolineritas, dan heteroskesdastisitas (Nugroho,2005).

\section{Kondisi Eksisting Panglima Laot Lhok}

\section{HASIL DAN PEMBAHASAN}

Panglima laot adalah nama lembaga adat di aceh yang masih bertahan hingga kini. Bisa dikatakan, panglima laot merupakan lembaga adat yang masih eksis saat ini. Keberadaan panglima laot di Aceh merupakan salah satu lembaga adat dari 13 lembaga adat yang masih berjalan. Keberadaan panglima laot di Aceh ini dilaksanakan seiring dengan disahkannya Qanun Aceh nomor 9 tahun 2008 tentang pembinaan kehidupan adat dan istiadat serta Qanun no.10 tahun 2008 tentang lembaga adat aceh yang merupakan penjabaran dari undang-undang nomor 11 tahun 2006 tentang pemerintahan aceh (UUPA) (Syahrizal Abbas, 2009).

Kedinamisan/ keaktifan panglima laot lhok di kecamatan masjid raya dapat dibuktikan dengan adanya kegiatan pelaksanaan kenduri laot setiap setahun sekali atau tergantung kesepakatan dengan nelayan, yang dihadiri oleh panglima laot, aparatur gampong, nelayan dan masyarakat sekitar. dan juga sampai pada saat ini nelayan masih sangat mematuhi terhadap hukum adat laot yang berlaku, hal ini dapat kita lihat di kecamatan masjid raya jarang sekali adanya perselisihan dan pelanggaran hukum adat laot. Jika saja panglima laot tidak ada/ tidak aktif maka mungkin saja penangkapan ikan yang tidak terkontrol (over fishing) akan terjadi sehingga mengalami penyusutan atau penurunan sumberdaya biota laut, dan ini akan beimbas kepada pendapatan nelayan yang semakin menurun. Oleh karena itu dengan aktifnya lembaga panglima laot dapat menjaga hukum adat laot sehingga pelanggaran, pertikaian dan perselisihan pendapat antar nelayan tersebut dapat diselesaikan oleh panglima laot yaitu dengan musyawarah.

Seseorang panglima laot dalam kedudukan sebagai pemimpin teratas dari persekutuan Adat Laot adalah orang terkemuka diantara para nelayan. Khususnya bagi seorang Panglima Laot Lhok atau Kabupaten. mereka memiliki pengetahuan lebih tentang seluk beluk kelautan dan telah berpengalaman sebagai Pawang Laot dan tentu saja menguasai dan memahami ketentuan hukum adat laot secara menyeluruh. Pada masa dahulu jabatan sebagai Panglima Laot bersifat turun temurun, akan tetapi pada saat sekarang ini jabatan panglima Laot terbuka bagi siapa saja asalkan memenuhi syarat (Usman, 2012). 
Lembaga Panglima Laot berkedudukan di wilayah laut dan berfungsi mengatur pengelolaan sumber daya alam di wilayah pesisir dan laut. Selain itu, Panglima Laot juga berfungsi membantu pemerintah daerah dalam menyukseskan pembangunan perikanan, melestarikan adat-istiadat dan kebiasaan-kebiasaan dalam masyarakat nelayan. Dalam melaksanakan fungsinya, Panglima Laot mempunyai tugas, antara lain memelihara dan mengawasi ketentuan-ketentuan hukum adat dan adat laut; mengkoordinasikan dan mengawasi setiap usaha penangkapan ikan di laut; menyelesaikan perselisihan/sengketa yang terjadi di antara sesama anggota nelayan atau kelompoknya; mengurus dan menyelenggarakan upacara adat laut; menjaga/mengawasi agar pohon-pohon di tepi pantai jangan ditebang; merupakan badan penghubung antara nelayan dengan pemerintah; dan meningkatkan taraf kehidupan nelayan pesisir pantai (Maya Muspita, 2008)

Struktur organisasi panglima laot mulai ditata pada musyawarah panglima laot Se Aceh di Banda Aceh pada juni 2002. Struktur panglima laot terdiri dari panglima laot di tingkat lhok, disingkat panglima lhok yang bertanggung jawab menyelesaikan konflik atau sengketa nelayan di tingkat lhok/mukim, bila perselisishan tersebut tidak selesai di tingkat lhok, maka diajukan ke tingkat yang lebih tinggi, yaitu panglima laot kabupaten. Yang disebut panglima laot Chik atau chik laot. Selanjutnya perselisihan mencakup antar kabupaten, provinsi atau bahkan internasional, maka akan diselesaikan di tingkat provinsi atau panglima laot provinsi (Aris Swantoro, 2015)

Hukum adat laot sangat menekankan pada pen_ngnya keseimbangan antara usaha untuk memenuhi kebutuhan ekonomi dengan kelestarian habitat serta keberlanjutan ekosistem. Konsep tersebut berhubungan dengan adanya keseimbangan vertikal dengan Sang Maha Pencipta dan horizontal sesama umat manusia. Larangan turun ke laut pada hari-hari tertentu seperti hari Jumat, hari raya dan hari-hari besar Islam termasuk peringatan tsunami setiap tanggal 26 Desember setiap tahunnya, bukan karena prosesi adat semata. Tujuan dari larangan tersebut antara lain untuk memberikan kesempatan bagi biota laut agar dapat berkembang biak dan untuk nelayan agar dapat memperbaiki kapalnya. Semua bekas perbaikan kapal tidak boleh dibuang sembarangan, termasuk melarang penggunaan alat-alat penangkapan yang_dak ramah lingkungan, bersosialisasi dengan sesama, terus meningkatkan ketakwaan kepada Tuhan YME, menjaga keseimbangan antara alam dengan mahluknya dan selalu mengenang peristiwa gempa bumi dan tsunami 26 Desember 2004 sebagai pelajaran berharga untuk selalu menjaga kelestarianalamnya (Sri Walny Rahayu, 2014)

\section{Peran Panglima Laot Lhok Dalam Pengelolaan Sumberdaya Laut Berbasis Adat}

Panglima laot adalah pemimpin nelayan yang secara hukum adat laot bertugas mengkoordinasikan satu atau lebih wilayah operasional nelayan, dan minimal satu pemukiman nelayan. Dengan demikian peran dan tanggung jawab panglima laot diantaranya mengawasi dan memelihara pelaksanaan hukum adat laut, menyelesaikan berbagai pertikaian sehubungan dengan penangkapan ikan, menyelenggarakan upacaraupacara adat laut dan lainnya. Mengingat peran panglima laot begitu besar dalam menjaga pelestarian fungsi laut, maka keberadaan lembaga panglima laot tersebut sangat dipertahankan oleh masyarakat pesisir. Dalam hukum adat laot telah dikembangkan sistem pelaporan untuk menjaga lingkungan laut. Jika seseorang nelayan atau masyarakat melihat ada oknum yang melanggar di laut, maka pelanggaran tersebut harus segera dilaporkan pada panglima laot guna untuk ditindak lanjuti pelanggaran tersebut. Pada penelitian ini peran panglima laot lhok diukur dengan menggunakan indikator 
memelihara dan mengawasi hukum adat laot, mengkoordinir setiap usaha penangkapan ikan di laut, menyelesaikan perselisihan / sengketa, mengurus dan menyelenggarakan upacara adat laot dan badan penghubung antara nelayan dengan pemerintah. Dari indikator memelihara dan mengawasi hukum adat laot dimana hasil penelitian diperoleh yaitu sebesar 72,5\% responden menjawab pada kategori Berperan, sebesar 22,5\% responden menjawab pada kategori Cukup Berperan dan 5\% berada pada kategori Kurang Berperan. Hasil penelitian yang didapat dari mengkoordinir setiap usaha penangkapan ikan di laut yaitu sebesar 50\% responden menjawab pada kategori Berperan, sebesar 47,5\% responden berada pada kategori Cukup Berperan dan selebihnya berada pada kategori Kurang Berperan. indikator menyelesaikan perselisihan / sengketa yang didapat dari hasil penelitian yaitu sebesar $62,5 \%$ responden berada pada kategori Berperan, sebesar 35,0\% berada pada kategori cukup berperan dan selebihnya berada pada kategori Kurang Berperan. indikator mengurus dan menyelenggarakan upacara adat laot yang didapat dari hasil penelitian yaitu sebesar $80 \%$ responden berada pada kategori Berperan, sebesar $20 \%$ berada pada kategori Cukup Berperan dan tidak ada yang menjawab dengan kategori Kurang Berperan. Untuk mengetahui peran panglima laot lhok dalam pengelolaan sumberdaya laut berbasis adat di Kecamatan Masjid Raya Kabupaten Aceh Besar secara keseluruhan dari jawaban responden dapat dilihat pada tabel berikut ini :

Tabel 2. Tingkat Peranan Panglima Laot Dalam Pengelolaan Sumberdaya laut berbasis adat

\begin{tabular}{cccc}
\hline \multirow{2}{*}{ No. } & Kategori Kinerja Aparatur Desa & \multicolumn{2}{c}{ Nelayan } \\
\cline { 3 - 4 } & & $\begin{array}{c}\text { Responden } \\
\text { (Orang) }\end{array}$ & $\begin{array}{c}\text { Persentase } \\
(\boldsymbol{\%})\end{array}$ \\
\hline 1. & Kurang Berperan $(24-39)$ & 0 & $0 \%$ \\
2. & Cukup Berperan $(40-55)$ & 6 & $15 \%$ \\
3. & Berperan $(56-72)$ & 34 & $85 \%$ \\
\hline & Jumlah & $\mathbf{4 0}$ & $\mathbf{1 0 0}$ \\
\hline
\end{tabular}

Sumber : Data Primer (diolah) Tahun 2018.

Dari tabel 5 dapa dilihat bahwa sebanyak $34(85 \%)$ responden menjawab pada kategori berperan. Dengan demikian dapat disimpulkan bahwa peran panglima laot lhok di Kecamatan Masjid Raya Kabupaten Aceh Besar sudah berperan baik. Peran panglima laot lhok yang berperan ini tentu tidak terlepas dari kerjasama panglima laot lhok dengan nelayan dalam pengelolaan sumberdaya laut berbasis adat, sehingga kendala/masalah yang dihadapi oleh nelayan dapat diselesaikan baik dengan musyawarah untuk pemecahan masalah tersebut atau dengan langsung ikut membantu.

Uji Faktor-Faktor yang mempengaruhi persepsi nelayan terhadap peran panglima laot lhok

Tabel 3. Hasil Uji Regresi Linier Berganda

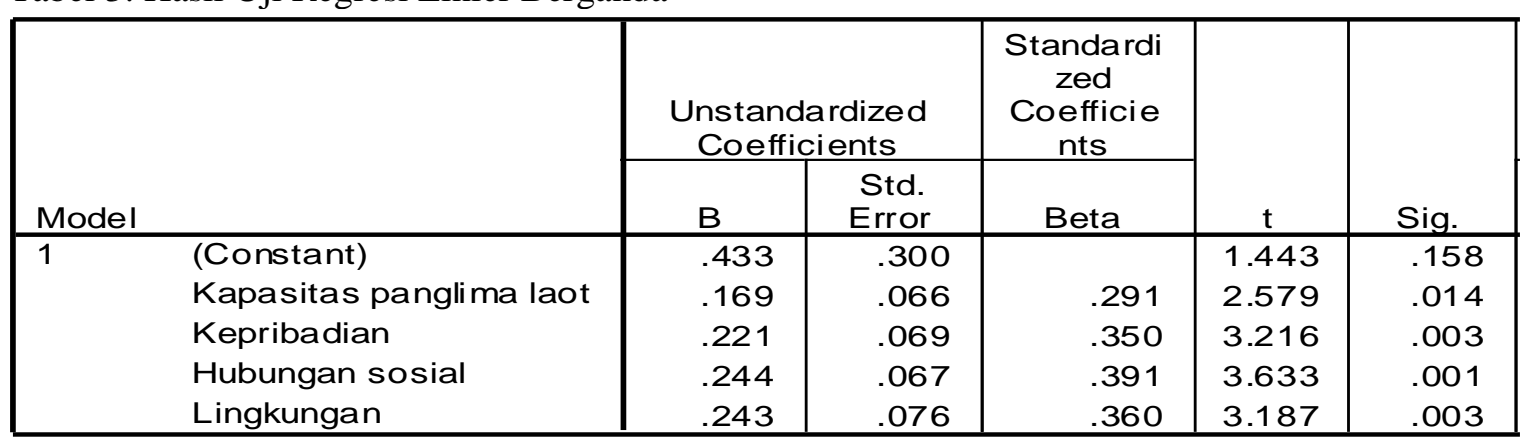

a. Dependent Variable: Peran Panglima Laot 
Dari hasil perhitungan statistik dengan menggunakan program SPSS seperti yang terlihat pada tabel diatas, maka diperoleh persamaan regresi linear berganda sebagai berikut :

$\mathrm{Y}=$ Peran Panglima Laot Lhok

$$
\mathrm{Y}=0,433+0,169 \mathrm{X}_{1}+0,221 \mathrm{X}_{2}+0,244 \mathrm{X}_{3}+0,243 \mathrm{X}_{4}
$$

$\mathrm{X}_{1}=$ Kapasitas Panglima Laot Lhok

$\mathrm{X}_{2}=$ Kepribadian

$\mathrm{X}_{3}=$ Hubungan Sosial

$\mathrm{X}_{4}=$ Lingkungan

\section{Uji t (Uji parsial)}

\section{a. Kapasitas Panglima Laot Lhok (X1)}

Hasil dari uji t variabel kapasitas panglima laot lhok (X1) menunjukkan bahwa nilai $t_{\text {hitung }}$ sebesar 2,579 dengan nilai signifikan sebesar 0,14 Sedangkan nilai $t_{\text {tabel }}$ sebesar 2,030 Karena nilai $t_{\text {hitung }}>t_{\text {tabel }}(2,579>2,030)$. sehingga Ha di terima dan sebaliknya Ho ditolak yang berarti nilai kapasitas panglima laot lhok berpengaruh signifikan terhadap peran panglima laot lhok. Dapat kita lihat bahwa Kapasitas panglima laot lhok merupakan faktor penting dalam pengelolaan sumberdaya laut dan menjaga hukum adat laot. Hal ini dikarenakan panglima laot lhok merupakan unit terdepan dalam menjalankan berbagai kegiatan yang ada dilaut seperti memelihara hukum adat laot, penggunaan alat tangkap yang ramah lingkungan serta menyeleaikan perselisihan/ sengketa

\section{b. Kepribadian (X2)}

Hasil dari uji t variabel kepribadian (X2) menunjukkan bahwa nilai $t_{\text {hitung }}$ sebesar 2,216 dengan nilai signifikan sebesar 0,003 Sedangkan nilai $t_{\text {tabel }}$ sebesar 2,030 Karena nilai $t_{\text {hitung }}>t_{\text {tabel }}(2,216>2,030)$. sehingga Ha di terima dan sebaliknya Ho ditolak yang berarti kepribadian berpengaruh signifikan terhadap peran panglima laot lhok. Dapat kita lihat bahwa kepribadian sangat menentukan peran seorang panglima laot karena kepribadian merupakan segala bentuk sifat dan tingkah laku yang khas yang dapat membedakan seorang individu dengan individu lainnya dalam menyesuaikan diri dengan lingkungan, pribadi manusia dapat berubah karena dipengaruhi oleh berbagai faktor, baik internal maupun eksternal.

\section{c. Hubungan Sosial (X3)}

Hasil dari uji t variabel hubungan sosial (X3) menunjukkan bahwa nilai $t_{\text {hitung }}$ sebesar 3,633 dengan nilai signifikan sebesar 0,001, Sedangkan nilai $t_{\text {tabel }}$ sebesar 2,030 Karena nilai $t_{\text {hitung }}>t_{\text {tabel }}(3,633>2,030)$. sehingga Ha di terima dan sebaliknya Ho ditolak yang berarti hubungan sosial berpengaruh signifikan terhadap peran panglima laot lhok. Artinya hubungan sosial mempengaruhi peran panglima laot lhok dalam menjalani tugasnya. Karena apabila hubungan sosial panglima laot dan nelayan tidak terjalin dengan baik maka hukum adat laot tidak akan berjalan sehingga banyak nelayan yang melanggar hukum adat laot yang sudah ditetapkan.

\section{d. Lingkungan (X4)}

Hasil dari uji t variabel lingkungan (X4) menunjukkan bahwa nilai $t_{\text {hitung }}$ sebesar 3,187 dengan nilai signifikan sebesar 0,003 Sedangkan nilai $t_{\text {tabel }}$ sebesar 2,030 Karena nilai $t_{\text {hitung }}>t_{\text {tabel }}(3,187>2,030)$. sehingga Ha di terima dan sebaliknya Ho ditolak yang berarti lingkungan berpengaruh signifikan terhadap peran panglima laot lhok. Artinya lingkungan mempengaruhi peran panglima laot lhok karena lingkungan kerja mempunyai peranan untuk meningkatkan atau bahkan menurunkan semangat kerja 
panglima laot dalam menjalankan tugasnya sebagai pemimpin adat laot. Lingkungan kerja panglima laot dapat dilihat dari bagaimana perilaku/ sikap panglima laot terhadap nelayan serta ada tidaknya konflik yang terjadi didesa tersebut.

\section{Uji F (uji simultan)}

Uji F pada penelitian ini merupakan uji yang dilakukan untuk melihat apakah terjadi pengaruh nyata antara peubah independent terhadap peubah dependent secara keseluruhan. Uji F diketahui dengan melihat signifikan $\mathrm{F}$ hitung apakah lebih besar dari alpha yang ditetapkan $(0,05)$ atau tidak. Untuk melihat besarnya pengaruh secara keseluruhan terhadap variabel yang akan diteliti maka dapat dilihat pada Tabel 17 berikut ini:

Tabel 4. Hasil Uji F

\begin{tabular}{|c|c|c|c|c|c|c|}
\hline \multicolumn{2}{|c|}{ Model } & $\begin{array}{c}\text { Sum of } \\
\text { Squares }\end{array}$ & $\mathrm{df}$ & Mean Square & $\mathrm{F}$ & Sig. \\
\hline \multirow[t]{3}{*}{1} & Regression & 1.480 & 4 & .370 & 13.744 & $.000^{\mathrm{a}}$ \\
\hline & Residual & .942 & 35 & .027 & & \\
\hline & Total & 2.422 & 39 & & & \\
\hline
\end{tabular}

a. Predictors: (Constant), Lingkungan, Kepribadian, Hubungan sosial, Kapasitas panglima laot

b. Dependent Variable: Peran Panglima Laot

Berdasarkan hasil Uji F ( secara simultan) diperoleh Fhitung sebesar 13,744 sedangkan $F_{\text {tabel }}$ pada tingkat signifikansi $\alpha=5 \%$ adalah sebesar 2,641. Hal ini menunjukkan bahwa pada Fhitung $>F_{\text {tabel }}(13,744>2,641)$ dengan tingkat signifikansi 0,000. Dari hasil perhitungan ini dapat diambil kesimpulan bahwa menerima Ha dan menolak Ho, artinya bahwa variabel Kapasitas Panglima Laot Lhok, Kepribadian, Hubungan Sosial Dan Lingkungan secara bersama-sama atau simultan berpengaruh secara signifikan terhadap peran panglima laot lhok di kecamatan masjid raya.

\section{KESIMPULAN DAN SARAN}

Adapun Kondisi eksisting panglima laot lhok dari hasil penelitian menunjukkan bahwa keberadaan panglima laot lhok di lokasi penelitian masih sangat diakui oleh masyarakat sekitar baik dikalangan nelayan, masyarakat biasa maupun pemerintah, karena Panglima Laot Lhok adalah pemimpin para nelayan dalam menjalankan hukum adat laot serta perpanjangan tangan perintah dalam menyukseskan pembangunan perikanan dan kelautan.

Peran Panglima Laot Lhok antara lain yaitu memelihara dan mengawasi hukum adat laot, mengkoordinir setiap usaha penangkapan ikan dilaut, menyelesaikan perselisihan/ sengketa dan mengurus serta menyelenggarakan upacara adat laot. Menurut hasil penelitian menunjukkan bahwa di Kecamatan Masjid Raya Panglima Laot Lhok sudah berperan dengan baik. Hal ini dapat kita lihat di lokasi penelitian jarang terjadi konflik atau permasalahan di laut. Peranan Panglima Laot Lhok yang sudah baik ini tentu tidak terlepas dari kerjasamanya dengan nelayan dalam pengelolaan sumberdaya laut dan menjaga hukum adat laot, sehingga kendala/ masalah yang dihadapi oleh nelayan pada saat melaut dapat diselesaikan dengan hukum adat laot melalui musyawarah untuk pemecahan masalah tersebut. 
Faktor -faktor yang mempengaruhi persepsi nelayan terhadap peran panglima laot lhok yaitu kapasitas panglima laot lhok (X1), kepribadian (X2), hubungan sosial (X3) dan lingkungan (X4). Dari hasil perhitungan dapat diambil kesimpulan bahwa menerima Ha dan menolak Ho, artinya bahwa variabel Kapasitas Panglima Laot Lhok, Kepribadian, Hubungan Sosial Dan Lingkungan secara bersama-sama atau simultan berpengaruh secara signifikan terhadap peran panglima laot lhok di Kecamatan Masjid Raya.

Dari hasil penelitian yang didapat bahwa kondisi eksisting (keberadaan) panglima laot di lokasi penelitian masih aktif , sebaiknya Untuk menunjang keaktifan/ kedinamisan lembaga panglima laot perlu adanya kegiatan-kegiatan lain seperti pelatihan untuk nelayan maupun kegiatan-kegiatan yang bersifat mendidik agar para nelayan dapat merasakan keberadaan dan fungsi nyata dengan adanya lembaga panglima laot. Panglima laot lhok diharapkan agar lebih memaksimalkan perannya dalam pelaksanaan pengawasan wilayah dari ancaman kerusakan dan lebih tegas dalam menjalankan hukum adat laot untuk menciptakan ketentraman dan kesejahteraan bagi masyarakat nelayan. serta pemerintah juga harus turut membantu agar memperkuat pengawasan dengan memberikan fasilitas seperti kapal kepada panglima laot dalam rangka mendukung pelaksanaan pengelolaan perikanan secara terpadu dan keberlanjutan. Panglima Laot lhok diharapkankan agar lebih memperkuat hubungan sosial dengan nelayan melalui kegiatan seperti gotong royong untuk membersikan pantai serta khanduri laot agar diselenggarakan setahun sekali tidak beberapa tahun sekali seperti yang telah dilaksanakan oleh panglima laot dulu.

\section{DAFTAR PUSTAKA}

Aris, S. 2015. Kontribusi Hukum Adat Dalam Pengembangan Hukum Laut di Indonesia, Jakarta

Gopakumar. 2002. Current State Of Overfishing And Its Impact On Suistainable Fisheries

Management In The Asia- Pacific Region, In RA oliver (eds), Suistanable

Fishery Managementin Asia. Asian Productivity Organization, Tokyo.

Kusnadi. 2012. Konflik Sosial Nelayan "Kemiskinan Dan Perebutan Sumber Daya Alam". Lkis Pelangi Aksara, Yogyakarta.

Maya, M. 2008. Kearifan Lokal Dalam Pengelolaan Sumber Daya Pesisir Dan Laut Hukum Adat Laot Dan Lembaga Panglima Laot Di Nanggroe Aceh Darussalam. Jurnal Kajian Kebudayaan. Vol 3-2.

Nazir.2003. Metode Penelitian. Ghalia Indonesia. Jakarta.

T Djuned. 2001. Pengelolaan Lingkungan Laut Oleh Panglima Laot. Laporan Penelitian. Universitas Syiah Kuala, Banda Aceh.

Sri Walny Rahayu. 2014. Lembaga Penyelesaian Sengketa Adat Laut "Panglima Laôt" di Aceh sebagai Bentuk Pengembangan Alternatif Penyelesaian Sengketa dalam Sistem Hukum di Indonesia. Jurnal Ilmu Hukum. Vol 1(3).

Sulaiman, 2013. Model Penyelesaian Konflik Alat Tangkap Perikanan di Aceh Barat. Jurnal Ilmu Hukum. Vol 15(1), 99-113.

Syahrizal, A. 2009. Mediasi Dalam Perspektif Hukum Syariah, Hukum Adat, dan Hukum Nasional, CIDA, Banda Aceh.

Usman. 2002. Sejarah Peradaban Aceh. Yayasan Obor Indonesia, Jakarta 